\title{
PANCASILA DALAM INTERAKSI KEARIFAN LOKAL DAN IDEOLOGI TRANSNASIONAL
}

\author{
Pradipto Bhagaskoro1, Rommel Utungga Pasopati², Syarifuddin ${ }^{3}$ \\ ${ }^{1}$ Peneliti Independen \\ email: bhagas.jpf@gmail.com \\ 2 Peneliti Independen \\ email: rommelpasopati@yahoo.com \\ ${ }^{3}$ Staf Ahli DPR RI Periode 2014-2019 \\ email: uddin.syarifuddin@gmail.com
}

\begin{abstract}
Today, 'transnational ideology' is much assumed as a threat for Indonesian local wisdom. Then, how can local wisdom survive amid the spread of transnational ideology? In essence, current recognized Indonesian religions, even coming from outside Nusantara, are well received because of their interaction with local conditions. These religions open, understand, and accommodate local conditions in order to conform to their teachings. The key point of religious life in Indonesia is the spectrum of its understanding with local wisdom. This paper describes the interaction between local wisdom and transnational ideology in Indonesia and how Pancasila should function in this condition. The first part of this paper describes local wisdom as a cultural product and its habitual manifestations. Second, explanations of transnational ideology and its relations to religions in Indonesia. Third, Pancasila is a reflection of local Indonesian wisdom and a path of interaction with any party, including transnational ideologies that are not yet understood. Fourth, conclusion that explains Pancasila as a form of nation-state presence that provides further understanding for local wisdom towards transnational ideology. This condition may happen as long as the spirit of mutual understanding becomes the basis for every interaction that may come.
\end{abstract}

Keyword: local wisdom; Pancasila; religion; transnational ideology.

\section{ABSTRAK}

Dewasa ini, istilah 'ideologi transnasional' banyak diperbincangkan sebagai asumsi ancaman bagi kearifan lokal di Indonesia. Lalu, bagaimana kearifan lokal dapat tetap bertahan di tengah persebaran ideologi transnasional? Pada dasarnya, agama-agama yang saat ini diakui oleh Pemerintah, meskipun berasal dari luar Nusantara, dapat diterima dengan baik karena interaksinya dengan kondisi lokal. Ajaran agama-agama tersebut membuka diri, memahami, dan mengakomodasi kondisi lokal supaya berkesesuaian dengan ajarannya. Ciri khas kehidupan beragama di Indonesia adalah spektrum perpaduan ajarannya dengan kearifan lokal. Tulisan ini memaparkan interaksi antara kearifan lokal dan ideologi transnasional di Indonesia, dan bagaimana Pancasila seharusnya berfungsi dalam kondisi ini. Bagian pertama dari tulisan ini memaparkan kearifan lokal sebagai produk kultural dan manifestasinya berupa kebiasaan-kebiasaan. Kedua, penjelasan tentang ideologi transnasional dan keterkaitannya dengan agama-agama yang ada di Indonesia. Ketiga, Pancasila adalah cerminan langsung dari kearifan lokal Indonesia dan jalan interaksi dengan pihak manapun, termasuk ideologi transnasional yang belum dipahami sekalipun. Keempat, kesimpulan yang menjelaskan Pancasila sebagai bentuk kehadiran 
negara yang memberi pandangan dan pemahaman lebih lanjut bagi kearifan lokal terhadap ideologi transnasional. Hal itu dapat terjadi sejauh semangat ingin saling memahami menjadi dasar bagi setiap interaksi yang ada.

Kata Kunci: agama; ideologi transnasional; kearifan lokal; Pancasila.

\section{PENDAHULUAN}

Kearifan lokal dalam bahasa Inggris sering dirujuk pada istilah local wisdom atau local genius. Local genius dapat diinterpretasikan sebagai sebuah bentuk identitas kebudayaan yang memungkinkan suatu komunitas untuk mampu menyerap dan mengolah kebudayaan diluarnya sesuai dengan kapasitas yang mereka miliki (Soebadio, 1986). Salah satu unsur kearifan lokal adalah lingkungan yang terbentuk (built environment). Unsur ini dipengaruhi oleh kebudayaan masyarakat dan juga faktor pendukung lainnya, meliputi iklim, kebutuhan akan perlindungan, material pembangunan, konstruksi, teknologi, karakter situs, ekonomi, pertahanan, dan agama (Rapoport dalam Dahliani, 2015). Local wisdom merupakan pengetahuan dasar yang didapatkan dari keseimbangan hidup dengan alam berdasarkan pengalaman dan kebenaran yang diperoleh dari kehidupan sehari-hari. Pengalaman melibatkan tubuh, jiwa, dan lingkungan di sekitarnya, yang kemudian terakumulasi dan diteruskan secara turun-temurun. Pola ini membentuk rasa hormat kepada leluhur, dan menghargai hal-hal yang bersifat moral daripada material (Nakorntap dalam Mungmachon, 2012). Sementara itu, terma kearifan lokal disarikan oleh Sonny Keraf sebagai segala bentuk pengetahuan, keyakinan, pemahaman, kebiasaan, dan etika yang menjadi pedoman manusia dalam berinteraksi dengan lingkungan ekologisnya (Keraf, 2006). Sifatnya yang diwariskan secara turun-temurun memungkinkan kearifan lokal berproses sebagai pembentuk identitas pada suatu komunitas lokal.

Indonesia merupakan negara-bangsa yang terdiri dari bermacam suku dengan kebudayaan yang berbeda-beda. Kekayaan budaya ini semakin dimungkinkan dengan kondisi geografis Indonesia yang berupa kepulauan dan disertai banyak gunung berapi. Kondisi ekologis yang unik ini berperan dalam membentuk masyarakat maritim dan agraris, yang dengan pengalamannya berinteraksi dengan alam menciptakan kearifan lokalnya masing-masing. Kondisi ini pula yang membentuk Pancasila dalam kerangka refleksi pemikiran kearifan lokal Indonesia. Kelima sila dalam Pancasila mencerminkan konstruksi sosial tentang apa yang telah dihidupi oleh masyarakat Indonesia sejak lama. Dengan demikian, Pancasila dapat diasumsikan sebagai benang merah dari kearifan lokal Indonesia yang beragam. Antara satu kearifan lokal dan yang lainnya mungkin saja berbeda, namun perbedaan itu tidak sama sekali menghilangkan intisari berbangsa dan bernegara Indonesia. Kondisi natural dan sosial Indonesia membentuk Pancasila yang mencerminkan sisi ketuhanan, individual, maupun sosial.

\section{TINJAUAN PUSTAKA}

Kearifan lokal termanifestasikan dalam kebiasaan ritualistik, pengetahuan, dan bagaimana suatu komunitas berinteraksi dengan kebudayaan dari luar komunitas tersebut. Kearifan lokal telah mengalami berbagai interaksi dengan kebudayaan diluarnya tanpa harus kehilangan cirinya sebagai identitas kultural suatu komunitas budaya tertentu. Namun belakangan muncul ketakutan terhadap terkikisnya kearifan lokal di Indonesia akibat gencarnya persebaran informasi dari seluruh dunia. Persebaran informasi turut membawa pemikiran-pemikiran yang sering diistilahkan sebagai ideologi transnasional. 
Ideologi transnasional dianggap dapat semakin mengikis kebiasaan-kebiasaan yang resiprok antar individu. Secara umum, ideologi transnasional berpijak pada kepastian pemahaman tentang cara pandang terhadap manusia dan sekitarnya. Jika kearifan lokal berasal dari pengalaman sehari-hari yang terkumpul dalam struktur kehidupan bersama yang cenderung tidak tertulis, ideologi transnasional memiliki teks tertentu yang dipandang sah sebagai cara pandang utama untuk melihat segala hal. Demikian pula kondisi Indonesia yang dipandang memprihatinkan baik dari sisi sosial, politik, maupun ekonomi, kemudian menjadi lahan subur bagi berkembangnya ideologi transnasional. Ideologi tersebut menawarkan jalan keluar praktis dari semua masalah tanpa perlu banyak berpikir. Hal itu jelas menjadi tantangan bagi kearifan lokal yang mempertimbangkan interaksi individu dengan alam, individu lain, maupun masyarakat. Kearifan tersebut berpikir bagaimana caranya mewujudkan keselarasan tanpa menyakiti pihak lain. Ideologi transnasional adalah sebaliknya dengan bersifat top-down, bersifat mengikat, bahkan benar tanpa harus diragukan sedikitpun.

Globalisasi pada era digital saat ini memungkinkan persebaran informasi yang tunggang-langgangbahkan tidak terkendali. Beberapa pihak menyebut bahwa saat ini dunia memasuki era 'post-truth', yakni era dimana kebenaran diperlakukan secara ekonomis, sehingga batas antara yang benar dan bohong, fiksi dan non-fiksi, menjadi kabur (Keyes, 2004). Pada sisi lain, informasi mengenai paham-paham yang belum dikenal sebelumnya dapat masuk dan dikonsumsi secara leluasa. Globalisasi memungkinkan informasi tersebar melampaui batas negara. Kebaruan informasi sendiri menjadi sebuah kebutuhan, dimana ketertinggalan terhadap informasi dapat berakibat pada kerugian ekonomi dan keterasingan sosial. Konsumsi informasi yang tidak terkendali itulah yang lalu memberikan jalan bagi ideologi transnasional untuk menemukan pasarnya yang lebih luas. Selain sebagai media untuk penyebaran informasi, globalisasi dimanfaatkan pula untuk menunjuk kondisi yang tanpa arah sehingga membutuhkan kepastian secara ideologis. Apa yang secara filosofis dipahami dalam interaksi antar manusia ingin digeser oleh pandangan tekstual murni yang pasti benar sekaligus baik bagi siapapun.

Ideologi transnasional secara longgar dapat dipahami sebagai paham atau pemikiran yang disebarkan secara lintas batas negara. Paham-paham yang masuk ke Indonesia juga datang bersama identitas yang mewakilinya. Hal yang dikhawatirkan sebagian masyarakat saat ini adalah kearifan lokal menjadi semakin inferior dari dalam kontestasinya dengan modernitas dan arus informasi yang secara gencar datang dari luar. Berbagai kalangan yang identitasnya terintegrasi dalam kearifan lokal tadi khawatir bahwa melemahnya daya saing kearifan lokal dapat mengikis identitas nasional masyarakat Indonesia, untuk kemudian tergantikan dengan ideologi transnasional yang masuk.

Ketakutan terhadap apa yang datang dari luar tidak hanya berlaku pada ranah paham dan ajaran saja. Ketakutan terhadap ideologi transnasional secara tidak langsung diiringi pula dengan sentimen anti asing. Sejak kerusuhan 1998, sentimen anti-asing kembali muncul di antara masyarakat dan mendapatkan momentumnya dengan tersedianya media sosial. Sebagian kalangan menekankan permusuhan ini kepada etnis Tionghoa, dengan membedakan antara pribumi dan non-pribumi.

Terma 'transnasional' pada ideologi transnasional sendiri pada dasarnya mencerminkan alienasi terhadap paham-paham selain Pancasila yang telah dibakukan oleh Pemerintah. Turunannya, ideologi transnasional secara umum dipersepsikan sebagai ancaman bagi nasionalisme dan kearifan lokal, dianggap tidak sesuai dengan kepribadian bangsa, dan mengancam persatuan dan kesatuan bangsa. Dari sinilah titik problematis muncul, yakni bahwa istilah ideologi transnasional sebenarnya bermasalah ketika ia dimaknai sebagai persepsi ancaman terhadap Pancasila sebagai cerminan kearifan lokal 
Indonesia. Gencarnya ideologi transnasional yang tersebar di ruang publik, dan perbincangan yang menyertainya belakangan ini tidak serta merta menggerus keberadaan kearifan lokal.

Dua dari banyak ideologi transnasional yang paling mengemuka saat ini adalah neoliberalisme dan fundamentalisme agama (Santosa, 2016). Neoliberalisme bertumpu pada kondisi pasar modern yang bukan hanya mengacu pada liberalisasi pasar dan investasi melainkan juga tren informasi dan teknologi modern yang merasuk ke dalam tiap sendi kehidupan sehari-hari. Neoliberalisme adalah ideologi untuk mewujudkan kebijakankebijakan pro-pasar dan kompromi terhadap kapital, di mana dasar premisnya adalah bahwa kompetisi merupakan satu-satunya cara yang masuk akal sebagai dasar aktivitas manusia. Fundamentalisme merujuk pada istilah untuk menggambarkan karakteristik yang diberikan kepada gerakan-gerakan relijius modern. Gerakan fundamentalis tidak serta merta tradisional, konservatif, dan ortodoks, namun gerakan ini cenderung reaktif terhadap konsep-konsep modernitas (E. Marty, 2015). Fundamentalisme merupakan gejala keagamaan yang bisa lahir dari semua agama dimana dan kapan saja. Dalam fundamentalisme Kristen misalnya, muncul untuk membendung modernisme yang dianggap menodai agama dan memilih kembali pada kemurnian teks kitab suci. Begitu pula dalam fundamentalisme Islam, diartikan sebagai usaha-usaha mempertahankan ajaran dasar Islam sesuai teks kitab suci yang murni tanpa konsep-konsep kebudayaan lain yang dianggap takhayul dan bid'ah (Zainuddin, 2015).

\section{METODE}

Berbagai penjelasan di atas lalu mendorong penulis untuk bertanya tentang 'bagaimana kearifan lokal dapat tetap bertahan terhadap ideologi transnasional di tengah arus informasi dewasa ini?'. Dapat dikatakan bahwa ideologi transnasional mengancam keberadaan kearifan lokal adalah sebuah kemungkinan daripada sebuah kepastian. Setiap aspeknya selalu dapat ditinjau ulang dalam rangka menyusun kembali strategi dan taktik terhadap berbagai hal yang mungkin muncul terutama dalam era globalisasi saat ini. Pertanyaan tersebut dijawab dengan merujuk pada metode penelitian kualitatif yang memaparkan relasi antara kearifan lokal dan ideologi transnasional dalam tulisan ini. Penjelasan dalam tulisan ini kemudian terbagi dalam beberapa sub-bab yaitu Pendahuluan, Kondisi Kearifan Lokal sebagai Pembentuk Kebudayaan, Dinamika Interaksi Kearifan Lokal dan Ideologi Transnasional di Indonesia, Pancasila sebagai Bagian Kearifan Lokal yang Adaptif terhadap Ilmu Pengetahuan, Kesimpulan, dan Referensi.

\section{HASIL DAN PEMBAHASAN}

\section{Kondisi Kearifan Lokal sebagai Pembentuk Kebudayaan}

Seperti yang sudah disebutkan sebelumnya, Indonesia merupakan negarabangsa yang terdiri dari dari bermacam suku bangsa dengan bermacam kebudayaan pula. Kondisi tersebut kemudian membentuk adanya bermacam-macam budaya sebagai hasil dari cipta, rasa dan karsa masyarakat sesuai suku bangsa yang ada. Koentjaraningrat menyebutkan bahwa:

Terma kebudayaan kemudian akan lebih mengerucut dan menjadi terma kearifan lokal. Hal ini seperti yang disebutkan oleh Sonny Keraf bahwa kearifan lokal sebagai segala bentuk pengetahuan, keyakinan, pemahaman, kebiasaan, dan etika yang menjadi pedoman manusia dalam berinteraksi dengan lingkungan ekologisnya (Keraf, 2006). Sifatnya yang diwariskan secara turun-temurun memungkinkan kearifan lokal berproses sebagai pembentuk identitas pada suatu komunitas lokal. Ida Bagus Brata memaknai kearifan lokal sebagai kebijakan manusia dan komunitas dengan bersandar 
pada filosofi, nilai-nilai, etika, cara-cara, dan perilaku yang melembaga secara tradisional mengelola berbagai sumber daya alam, hayati, manusia dan budaya untuk kelestarian sumber daya tersebut bagi kelangsungan hidup berkelanjutan (Brata, 2016:11). Kemudian, Haryati Subadio menyebut bahwa kearifan lokal secara keseluruhan meliputi bahkan mungkin dapat dianggap sama dengan identitas atau kepribadian budaya suatu bangsa (Soebadio dalam Brata, 2016).

Dari beberapa definisi tersebut, terlihat bahwa kearifan lokal merupakan upaya adaptasi kelompok masyarakat dengan lingkungan sekitarnya. Berkat kearifan lokal ini, masyarakat dapat menjalankan kehidupannya bahkan dapat berkembang secara berkelanjutan (Permana dalam Alfian, 2013). Selain itu, kearifan lokal juga membentuk identitas lingkungan mereka dan membedakan satu kelompok masyarakat dengan kelompok lainnya. Dengan kondisi geografis yang luas, tentu saja kemudian Indonesia memiliki bermacam-macam kearifan lokal yang muncul dari setiap suku bangsa yang ada. Oleh karena itu, kearifan lokal merupakan bagian dari kekayaan budaya masyarakat yang dimiliki oleh negara dan bangsa Indonesia.

Kearifan lokal secara subtantif bisa berupa aturan mengenai kelembagaan dan sanksi sosial, ketentuan mengenai pemanfaatan ruang dan perkiraan musim bercocok tanam, pelestarian perlindungan terhadap kawasan sensitif, serta bentuk adaptasi dan mitigasi tempat tinggal terhadap iklim, bencana dan ancaman lainnya (Ernawi dalam Wikantiyoso dan Tutuko, 2009:8). Substansi kearifan lokal yang disebutkan Ernawi menunjukkan bahwa upaya sebuah masyarakat untuk beradaptasi dengan lingkungan alam sekitar mereka diatur secara rinci dan terencana. Masing-masing aturan dan norma yang ada mengatur setiap perilaku masyarakat dalam kelompok tersebut. Kemudian diatur juga mengenai sanksi yang didapat ketika terdapat anggota kelompok yang melanggar aturan yang sudah menjadi kesepakatan tersebut. Dalam bagian ini, kearifan lokal yang dijabarkan hanya dibatasi pada kebudayaan Minang dan Jawa.

\section{a. Kearifan Lokal Minang}

Seperti yang sudah disebut oleh Ernawi bahwa kearifan lokal secara substantif meliputi empat hal yang sudah disebut sebelumnya (Ernawi dalam WIkantiyoso dan Tutuko, 2009:8). Substansi kearifan lokal ini terlihat pula dalam kehidupan masyarakat Minang. Mereka mengenal istilah "alam takambang jadi guru" yang merupakan landasan berpikir atau manifestasi masyarakat Minang dalam berkehidupan (Alfian, 2013:428). Istilah ini sendiri berarti bahwa alam dengan segala isinya menjadi sebuah pembelajaran hidup bagi masyarakat Minang. Pengenalan adat-istiadat falsafah kehidupan tersebut diturunkan baik secara lisan maupun tulisan. Adat istiadat ini biasanya dituturkan dan ditulis dalam dalam bentuk pepatah dan pantun yang disampaikan oleh pemangku adat dalam upacara-upacara tertentu.

Menurut Alfian, terdapat empat unsur yang harus dipatuhi oleh setiap masyarakat Minang yaitu saiyo sakato, sahino samalu, anggo tango, dan sapikue sajinjiang (seia sekata, sehina semalu, angga tangga/berjenjang, sepikul sejinjing) (Alfian, 2013:428). Keempat unsur ini membentuk masyarakat Minang yang menjunjung tinggi musyawarah mufakat atau yang dalam bahasa Minang disebut sakato. Musyawarah mufakat ini dilakukan untuk untuk mencapai kesepakatan terbaik bagi semua pihak. Keputusan yang diambil tidak harus bulat tetapi harus menghargai perbedaan pendapat yang ada (Alfian, 2013:428). Meskipun demikian, jika keputusan sudah diambil, maka semua harus menjalankan keputusan tersebut tanpa terkecuali. 
Menurut M. S. Amir, adat Minang mendorong anggota masyarakatnya untuk selalu menjaga kebersamaan (M. S. Amir dalam Alfian, 2013:429). Kondisi inilah yang juga tercermin dalam kehidupan masyarakat Minang terkait tanggung jawab bersama. M.S. Amir mencatat bahwa dalam pepatah Minang terdapat bait yang berbunyi "Yang berat sama dipikul, yang ringan sama dijinjing; ke bukit sama mendaki; ke lurah sama menurun; yang ada sama dimakan; yang tidak sama dicari" (M. S. Amir dalam Alfian, 2013:428). Bait tersebut merupakan petuah dimana masyarakat Minang harus saling membantu dengan mengutamakan gotong-royong dan kebersamaan masyarakat.

Selain itu, adat Minang juga mengatur mengenai etika kesopanan dalam bergaul. Etika kesopanan ini mengatur agar masing-masing anggota masyarakat harus saling menghormati dan menjaga perilakunya. Aturan ini tertuang dalam pepatah yang berbunyi "Yang tua dihormati, yang kecil disayangi, sama besar bawa berkawan, ibu dan ayah diutamakan" (Alfian, 2013:428). Pepatah ini menunjukkan bahwa masyarakat Minang sudah diajarkan bahwa saling menghormati merupakan inti dalam bersosialisasi. Sopan santun berdasarkan umur dan tingkatan dalam keluarga juga diajarkan bahwa orang tua merupakan hal yang utama. Disamping itu, Alfian mencatat bahwa terdapat hal menarik terkait adat Minang mengenai ketertiban dalam masyarakat (Alfian, 2013:429). Menurut adat Minang, yang memerintah bukanlah orang, melainkan kebenaran yang dihasilkan dari mufakat dan sesuai dengan logika yang disebut dengan alue dan patuik atau berdasarkan aturan yang pantas.

Dari hal tersebut, terlihat bahwa kearifan lokal masyarakat Minang melalui adat istiadat yang diatur dalam pepatah-pepatah masyarakat menjadi pedoman hidup masyarakat Minang. Nilai dan norma yang terkandung dalam pepatah tersebut dijalankan dan diturunkan untuk menjadikan masyarakat Minang sesuai dengan apa yang dikehendaki oleh leluhur mereka. Kaitannya dengan ajaran agama, pepatah tersebut banyak yang bersesuaian dengan ajaran agama, terutama Islam. Penghormatan kepada sesama terutama orang tua sejalan dengan ajaran agama Islam bahwa seorang muslim harus menghormati orang tua dan mengasihi yang lebih muda sebagaimana hadits Nabi Muhammad SAW yang diriwayatkan oleh Thabrani dan Dhamrah bahwa "Tidak termasuk golongan kami orang yang tidak menyayangi kepada orang yang lebih kecil (muda) dan tidak mengetahui kewajibannya terhadap orang yang lebih besar (tua)." (Majid, 2016). Hal ini juga didukung melalui firman Allah SWT dalam Al Quran surat An Nisa' ayat 36 yang berarti "sembahlah olehmu kalian Allah dan jangan sekutukan sesuatu apapun dengan Dia! Dan bersikap baik kamu kalian kepada dua orang tua dengan sikap baik yang sesungguhnya" (Muzadi, 2006). Konsep menghormati orang tua ini sendiri ditempatkan sebagai kewajiban kedua setelah beribadah kepada Allah SWT.

Dalam hal ini terlihat bahwa adat-istiadat masyarakat Minang dengan ajaran agama Islam terdapat kesesuaian terlihat dalam konsep etika berperilaku dan penghormatan kepada orang tua. Inti dari keduanya adalah bahwa menghormati orang tua dan menyayangi yang lebih muda merupakan konsep kebaikan umum yang tidak bertentangan dengan ajaran agama dan justru agama menempatkannya sebagai sebuah etika berperilaku yang harus pula dianut. Oleh karena itu, dalam hal ini, kearifan lokal dan agama yang masuk terjadi akulturasi dan asimilasi yang justru memperkuat identitas budaya setempat. Bahkan dalam 
nilai dan norma yang berlaku di masyarakat, keduanya saling mengisi untuk membentuk kebudayaan yang berciri khas.

\section{b. Kearifan Lokal Jawa}

Jika merujuk pada pulau Jawa, terdapat dua kebudayaan besar yang ada yaitu kebudayaan Jawa dan kebudayaan Sunda. Tulisan ini akan mengerucutkan pada kebudayaan Jawa. Mengulas mengenai kearifan lokal suku Jawa akan sangat terkait dengan penelitian dari Clifford Geertz yang membagi masyarakat Jawa ke dalam tiga golongan yaitu priyayi, santri dan abangan (Robertson dalam Marzuki, Nd.:6). Ketiga konsep tersebut erat kaitannya dengan sejarah masyarakat Jawa itu sendiri. Sejak era pra Hindu-Buddha, era Hindu-Buddha, hingga masa kerajaan Islam, terdapat satu kearifan lokal yang selalu melekat dalam terminology modern disebut sebagai animisme dan dinamisme (kapitayan), kepercayaan terhadap leluhur dan kepercayaan terhadap hal gaib yang selalu mengakar (Simuh, 1996:110). Kedatangan agama mulai Hindu, Buddha, hingga Islam ternyata tidak menghilangkan kepercayaan tersebut, tetapi bahkan memberikan pemahaman dan interpretasi yang baru dan unik, sehingga terjadi akulturasi budaya antara kearifan lokal Jawa dengan ajaran agama tersebut.

Selain itu, menurut Koentjaraningrat, masyarakat Jawa terutama Islam Kejawen aktivitasnya dipengaruhi oleh keyakinan, konsep-konsep, dan pandangan, nilai-nilai budaya, dan norma-norma yang kebanyakan berada di alam pikirannya (Koentjaraningrat dalam Marzuki, Nd.:8). Sikap ini kemudian melahirkan masyarakat yang bersifat lebih toleran, yang lebih menghindari untuk mempertentangkan keyakinan relijiusnya masing-masing. Pengalaman relijius dipandang sebagai penghayatan kebatinan yang sifatnya unik dan personal bagi masing-masing individu. Dengan demikian perdebatan mengenai olah ritual dan keyakinan yang sifatnya spiritual lebih mudah dihindari. Kondisi ini yang kemudian membuat masuknya agama-agama di Jawa relatif mudah diterima dan membaur dengan kebudayaan masyarakat setempat.

Persinggungan kearifan lokal Jawa dengan ajaran agama yang masuk tersebut kemudian menghasilkan bentuk-bentuk akulturasi dan asimilasi yang masih dapat dilihat sampai saat ini. Dapat dilihat bahwa kepercayaan masyarakat Jawa kepada roh dan makam para leluhur yang dalam ajaran fundamental Islam dapat dikategorikan sebagai khurafat dan takhayul, ketika kemudian diberikan pendekatan ajaran Islam yang inklusif mengenai ziarah kubur mengalami penyesuaian tanpa harus dipaksakan untuk dihapus dan diantagoniskan. Dalam hal ini ritual sesembahan masyarakat kemudian berganti menjadi ritual doa kepada Allah SWT melalui perantara (wasilah) orang-orang saleh seperti Wali Songo dan Kyai. Kearifan lokal inilah yang sampai sekarang masih berkembang dan menjadi identitas bagi masyarakat Jawa. Selain itu, terdapat kearifan lokal lain berupa upacara dan perayaan seperti Sekaten, Grebeg, Labuhan, Slametan, Ruwatan, Nyadran, Tirakat, Wayang, dan Ziarah Makam.

Menurut Agus Sunyoto, kearifan lokal Jawa yang terlihat saat ini tidak terlepas dari dakwah Wali Songo (Sunyoto, 2016:434). Wali Songo mengubah nilai keagungan, kemuliaan, kebesaran, keunggulan dan penaklukan yang lekat dengan Majapahit menjadi nilai-nilai moral yang terkenal halus, santun, luhur, dan penuh empati seperti nilai kesabaran (shabar), keikhlasan (ikhlas), andhap asor (tawadhu'), keadilan (adl'), guyub rukun (ukhuwah), kerelaan (ridha), kesederhanaan (wara'), nrimo (qana'ah), eling (dzikir), ngalah (tawakal), dan 
ngalah (lillah). Selain itu, kebiasaan masyarakat yang masih lekat dengan ajaran kapitayan (animisme-dinamisme) dan Hindu-Buddha secara perlahan disesuaikan dengan ajaran agama Islam seperti (1) kebiasaan Samadhi sebagai puji mengheningkan cipta diubah menjadi sholat wajib, (2) kebiasaan sesaji dan ketutug diubah menjadi pemberian shodaqoh, (3) adat kebiasaan yang meniru dewa dalam upacara perkawinan seperti menanam pohon Klepu dewandaru, menabuh gamelan lokananta, nyanyian wanita yang mengelu-elukan kehadiran dewa dalam gerak tari tayuban, dihilangkan dengan jalan kebijaksanaan sehingga membuka hati rakyat banyak (Zarkasi dalam Sunyoto, 2016:434). Jika diperinci lagi, ada beberapa ritual lain sebagai kearifan lokal Jawa yang bersinggungan dengan ajaran agama Islam seperti:

\section{Slametan}

Menurut Clifford Geertz, slamet berarti gak ana apa apa atau tidak akan terjadi apa-apa yang dapat merugikan (Geertz dalam Marzuki, Nd.:13). Slametan merupakan kegiatan komunal masyarakat Jawa untuk memperingati sesuatu baik itu upacara kelahiran, perkawinan, niat tertentu maupun kematian. Beberapa acara Slametan yang masih lestari yaitu walimahan ketika upacara perkawinan dan slametan untuk memperingati kematian 7 hari, 40 hari, 100 hari, 1 tahun dan 1000 hari. Slametan kematian ini bernama tahlilan karena biasa diisi dengan pembacaan kalimat thoyyibah yang terangkum dalam tahlil. Menurut Salahudin, tetap lestarinya Slametan karena memiliki efek psikologis dalam bentuk keseimbangan emosional dan masyarakat, yangmeyakini bakal selamat, tidak terkena musibah atau malapetaka, setelah melakukan kegiatan ini (Salahudin dalam Marzuki, Nd.:15).

\section{$>\quad$ Nyadran}

Nyadran berasal dari upacara Sraddha, yaitu berkirim doa kepada arwah leluhur (Sunyoto, 2016:438). Dalam tradisi Jawa kuno, nyadran atau sraddha dipimpin oleh bhiksu dan diselenggarakan mulai bulan Srawana (JuliAgustus) dan bulan Bhadrawada (Agustus-September). Sedangkan setelah terjadi asimilasi dengan Islam, nyadran dipimpin oleh modin dan mengalami pergeseran waktu yaitu pada bulan Sya'ban atau Ruwah (Marzuki, Nd.:17).

Jika dilihat dalam perkembangannya, kearifan lokal Jawa saat ini memang lekat kaitannya dengan ajaran agama Islam. Banyak ritual-ritual kejawen yang terasimilasi dengan ajaran Islam. Menurut KH. Abdurrahman Wahid, usaha dakwah Wali Songo diatas yang kemudian terasimilasi dengan budaya Jawa bisa disebut dengan pribumisasi Islam (Wahid dalam Sunyoto, 2016:438). Beberapa hal yang menjadi bukti pribumisasi Islam ini selain kearifan lokal tradisi yang masih lestari diatas juga adanya penggantian bahasa Arab menjadi bahasa setempat. Hal ini terlihat dari pengistilahan Gusti Kang Murbeng Dumadi menggantikan sebutan Allahu Rabbil Alamin, Kanjeng Nabi untuk menyebut Nabi Muhammad SAW, Kyai untuk menyebut al alim, Guru untuk menyebut ustadz, pesantren untuk menyebut ma'had, sembahyang untuk menggantikan istilah shalat, upawasa atau puasa untuk mengganti istilah shaum, langgar untuk menyebut mushalla, dan beberapa pengistilahan lainnya (Sunyoto, 2016:438). 
Fakta-fakta mengenai kearifan lokal Jawa ini menunjukkan bahwa antara ajaran agama yang datang dari luar masyarakat dapat disesuaikan, diadaptasikan, bahkan disubstitusikan dengan norma, nilai, dan tradisi lokal masyarakat dengan baik. Asimilasi dan akulturasi yang terjadi pada masyarakat Jawa menunjukkan bahwa mereka tetap menerima ajaran agama karena dianggap sesuai dengan keyakinan mengenai leluhur, hari-hari keramat, dan kepercayaan lain. Upacara-upacara yang terkait keyakinan tersebut tidak hilang dengan masuknya agama, tetapi justru agama memperkuat adanya upacara tersebut dengan penyesuaian dengan ajaran agama.

Oleh karena itulah, sudah seharusnya masuknya ideologi transnasional ke Indonesia dalam beberapa tahun terakhir tidak berusaha untuk menghilangkan aspekaspek lokalitas yang ada di Indonesia, namun harus memperkuat keberagaman budaya yang ada tanpa menghilangkan salah satunya. Hal ini dikarenakan saat ini seringkali terjadi Islamisasi pribumi yang bukan membuka Islam menjadi rahmat bagi setiap manusia melainkan sebaliknya yaitu adanya upaya membuat Indonesia serupa dengan budaya Arab. Proses tersebut meniadakan budaya lokal padahal seharusnya agama menyatu dengan kebiasaan daerah masing-masing dan bukan malah mendikte bagaimana identitas yang sudah menyejarah harus hidup dan berkembang

\section{Dinamika Interaksi Kearifan Lokal dan Ideologi Transnasional di Indonesia}

Dari penjelasan tentang kearifan lokal di atas, terlebih dengan diterimanya konsep nasionalisme sebagai bangsa Indonesia, terdapat kecenderungan bahwa segala sesuatu apa yang berasal dari luar negeri diasumsikan akan mengancam eksistensi segala sesuatu yang sifatnya lokal dan dengannya juga dianggap mempengaruhi stabilitas nasional. Kecenderungan ini semakin besar karena gencarnya perputaran informasi memberi wawasan terhadap banyak hal (di mana di dalamnya termasuk ideologi-ideologi) tanpa kecepatan, kesiapan dan kematangan untuk mengolah informasi-informasi tersebut. Kepungan informasi ini memicu reaksi defensif yang kemudian dapat dilihat melalui upaya-upaya alienasi dan melihat hal-hal tersebut sebagai persepsi ancaman. Dari persepsi ancaman inilah yang kemudian memicu kecurigaan dan pandangan atau stigma negatif yang secara deterministik dianggap pasti memberi dampak buruk bagi bangsa. Hal tersebut secara sama juga tampak pada usaha membentengi kearifan lokal dari derasnya arus pandangan dari luar negeri ini.

Tulisan ini tidak berusaha untuk memberi batasan benar atau salah pada pandangan bahwa sesuatu yang asing pasti berdampak negatif dalam rangka mempertanyakan apa yang dimaksud dengan hal tersebut, namun yang menjadi masalah adalah ketika ketidaktahuan itu bukan dijawab dan diselesaikan melainkan dilanggengkan sebagai asumsi yang tidak sesuai dengan realitas. Maka, sangat perlu untuk memaknai kembali apa itu ideologi dan kondisi transnasional dan bagaimana keduanya bersinggungan secara umum dan religius dengan kearifan lokal Indonesia.

Kecenderungan untuk menganggap ideologi transnasional mengancam kearifan lokal perlu ditinjau ulang agar pernyataan tersebut dianggap sebagai sebuah kemungkinan daripada kepastian. Apa yang disebut dengan ideologi berasal dari idea yang berarti pemikiran dan logos yang berdefinisi pengetahuan dalam bahasa Yunani. Ideologi secara verbatim dimaknai sebagai struktur pemikiran dan nilai dalam tatanan pengetahuan tertentu. Secara umum, konsep ini berciri khas pada suatu pembenaran tertentu yang membedakan diri serta dibedakan dari konsep yang lain (Barker, 2014:139). Transnasional secara harfiah berarti melewati batas negara baik itu berupa yang terlihat seperti barang dan jasa maupun yang tak terlihat seperti ideologi dan agama. Kondisi transnasional ini makin diperluas pada konteks globalisasi dari hanya 
negara menjadi aktor pribadi, kelompok masyarakat, hingga perusahaan bertaraf multinasional (Viotti dan Kauppi, 1999:498). Ideologi transnasional sendiri lebih mengarah pada pola struktur pengetahuan lintas batas negara yang menyebar lewat media informasi. Di Indonesia, pola pengetahuan ini melewati masa kerajaan, republik, hingga globalisasi.

Dalam konteks sejarah Indonesia, ada tiga ideologi yang secara dominan berperan membentuk tatanan pengetahuan, yaitu liberalisme, nasionalisme, dan sosialisme. Ketiga hal ini berasal dari luar negeri namun dipahami sebagai cerminan atas kondisi di Indonesia. Pada masa Perang Dingin, ketiga ideologi tersebut makin mengemuka berbasis massa di Indonesia. Liberalisme cenderung berbasis pada manusia dengan sisi individualitas, kebebasan, dan otonominya. Manusia dipandang mampu mengatur dirinya sendiri tanpa adanya intervensi pihak lain. Pada sisi sosial budaya, konsep ini bertumpu pada kebebasan manusia yang hakiki dan tidak dapat diganggu gugat. Hal ini nantinya turut membentuk konteks Hak Asasi Manusia dan penghargaan lebih jauh terhadap kualitas-kualitas individu. Secara ekonomi, pandangan ini bertumpu pada kondisi pasar bebas yang sebagai sistem ekonomi di kemudian hari disebut dengan neoliberalisme dengan menekan peran negara seminimal mungkin dan mengupayakan penguasaan swasta dalam ekonomi. Hal ini membentuk apa yang dinamakan sebagai pasar saham, industrialisasi, dan swastanisasi di Indonesia. Liberalisme ekonomi menjadi tumpuan sejak pemerintahan Soeharto dan kecenderungannya kepada neoliberalisme semakin terasa hingga pemerintahan Presiden Joko Widodo.

Selanjutnya, nasionalisme memegang teguh semangat kebangsaan sebagai bentuk cinta bangsa dan tanah air. Konsep ini biasanya dimaknai dengan menjunjung tinggi potensi dalam negeri, kemandirian ekonomi, tanpa perlu bergantung pada pihak asing dalam menghadapi sistem pasar dunia. Nasionalisme mengharapkan rasa cinta tanah air yang diwujudkan dalam bentuk sikap dan perilaku masyarakat sebagai bakti terhadap bangsa dan/atau negara. Bentuknya mencakup kepatuhan terhadap hukum dan peraturan, memakai produk dalam negeri, mengikuti wajib militer, dan lain sebagainya.

Nasionalisme di Eropa kerap dianggap sebagai ancaman karena kedekatannya untuk teradikalisasi menjadi ultra-nasionalisme yang fasistik seperti Nazi German atau Kekaisaran Jepang pada Perang Dunia II. Namun Soekarno mengkonsepsikannya sebagai nasionalisme yang humanistik, bukan seperti nasionalisme yang menganggap diri sebagai bangsa terbaik, namun nasionalisme yang berlandaskan pengakuan atas kemanusiaan. Nasionalisme dipandang sebagai alat perjuangan kemerdekaan Indonesia, dan bagi Sukarno nasionalisme Indonesia harus hidup dalam 'tamansari' internasionalisme (kerjasama antar bangsa yang setara, dilandasi solidaritas kemanusiaan). Nasionalisme dalam konsep Soekarno ini menjadi alat perjuangan untuk membangun bangsa secara sosial maupun ekonomi pada masa itu.

Pada aspek lain, sosialisme melihat sisi sosial sebagai titik tumpu utama keberlangsungan Indonesia. Pandangan ini adalah antitesis dari liberalisme ekonomi karena bukan berbasis individualisme melainkan kolektivisme. Dalam pandangan ini, segala sumber daya yang dimiliki bumi Indonesia harus diolah negara dan didistribusikan secara merata kepada warganya. Kepemilikan individu dibatasi dan diredistribusikan sama rata kepada warga lainnya. Wacana ini secara longgar mengemuka kembali pada era pasca reformasi dengan konsep pemerataan sosialekonomi setelah sebelumnya muncul di era pergerakan nasional dan masa Soekarno berkuasa. 
Pada era pasca Perang Dingin, ketiga ideologi diatas meluas lingkupnya dari sentralisasi politis ke arah ekonomi. Setelah bangkrutnya sosialisme-komunisme di akhir abad-20, liberalisme menjadi acuan utama kehidupan berbangsa dan bernegara. Masyarakat Indonesia makin melihat dirinya dalam bingkai kebebasan, kesetaraan, dan kemanusiaan. Demikian pula hak individu makin meluas disertai dengan liberalisasi ekonomi di berbagai bidang (Santosa, 2016). Ideologi yang terkesan politis menjadi bentuk lain yaitu kultural dalam nada kekuasaan. Sejauh liberalisme memegang dominasi, hampir semua hal menjadi bebas karena paham ini menjadi dasar atas reproduksi kekuasaan. Demikian pula tansnasionalisme yang menjadi ciri khas ideologi transnasional sekaligus tercerminkan dalam kondisi internal domestik Indonesia. Globalisasi dalam konteks liberal pun makin dirasakan dampaknya di kehidupan sehari-hari masyarakat Indonesia. Makin banyak orang dapat berusaha memperjuangkan kebebasan hak individualnya, makin pula gobalisasi dipeluk sebagai keutamaan. Ciri khas yang sama juga terpahami dalam masa teknologi informasi yaitu kepemilikan yang makin merata. Kapital dalam bidang informasi adalah tentang bagaimana individu dan tatanan sosial lain dapat memanfaatkan informasi sebagai inti kekuasaannya. Individu tidak perlu menjadi politis untuk memeluk semacam kondisi liberal karena kebebasan telah menjadi pengandaian utama dalam masa globalisasi saat ini.

Dari ketiga macam ideologi di atas, terlihat bahwa sebenarnya meskipun ketiganya berasal dari luar negeri namun tidak sepenuhnya asing bagi masyarakat Indonesia. Pancasila sebenarnya telah merefleksikan pemikiran transnasional tersebut dalam interaksi dengan kearifan lokal (Sunoto, 1989:20-25 dan 104-109). Penghargaan terhadap kebebasan dan individu telah lama dipahami oleh masyarakat Indonesia bahkan tercermin dalam sila kedua Pancasila. Kondisi kemerdekaan pasca penjajahan yang mendorong nasionalisme dalam pembangunan jelas menjadi tumpuan utama kebangkitan bangsa ini seperti dalam Persatuan Indonesia pada sila ketiga Pancasila. Pemerataan sebagai cita-cita bersama juga adalah bentuk sosial masyarakat Indonesia baik terlihat dalam Preambule UUD 1945 maupun sila keempat dan kelima Pancasila. Pada kenyataannya, apa yang berasal dari luar negeri belum tentu tidak sesuai dengan pandangan hidup masyarakat Indonesia karena bagaimanapun juga negeri ini adalah multikultural (Gunadha dalam Tjahjadi, 2011:12-13). Negeri sebesar Indonesia jelas mungkin selalu bersentuhan dengan ideologi transnasional. Demikian pula kearifan lokal berhadapan dengan keasingan yang mungkin dapat dimengerti maupun tidak.

Hal yang menjadi titik masalah adalah apabila ideologi tersebut ditarik hingga titik terjauhnya atau apa yang lazim disebut dengan polemologi. Dengan kata lain, ideologi transnasional menjadi polemik jika hal tersebut dimutlakkan sebagai sebuah keharusan bagi masyarakat. Neoliberalisme, chauvinisme, dan komunisme adalah polemik dari absolutisme ideologi transnasional karena ketiganya sungguh asing bagi masyarakat Indonesia. Demikian pula halnya dengan keberadaan neoliberalisme dan fundamentalisme agama. Selain itu, ideologi-ideologi tersebut jelas tidak sesuai dengan kearifan lokal karena masyarakat Indonesia adalah masyarakat yang kompleks dan tidak monolitik. Kompleksitas ini membawa kearifan lokal bukan pada refleksi sebuah kemutlakan ideologi melainkan pandangan hidup. Masyarakat Indonesia mengakomodasi hak individu, nilai kebangsaan, dan kebersamaan sosial, sejauh semuanya dihidupi secara intersubjektif tanpa harus saling menegasi satu sama lain.

Masyarakat Indonesia sesungguhnya terbuka pada semua hal namun yang seringkali terjadi adalah kesalahpahaman atas keterbukaan ini. Keterbukaan tersebut 
dimaknai sebagai ketiadaan jati diri yang menjadi pintu masuk bagi kemutlakan ideologi tertentu (Santosa, 2016). Pada kenyataannya, bukan lalu masyarakat Indonesia tidak memiliki jati diri, justru keberagaman pemikiran itulah yang menghidupi dan dihidupi sebagai jati diri masyarakat Indonesia (Sunarko dalam Tjahjadi, 2011:103-104). Hal tersebut sama halnya dengan Pancasila yang lebih cocok dipahami sebagai pandangan hidup daripada ideologi yang mutlak. Bangsa Indonesia mengalami perubahan namun dengan mempertimbangkan aspek lain bahkan yang sungguh berbeda sekalipun. Masyarakat Indonesia memandang pemahaman transnasional tidak selalu senada dengan ideologi transnasional. Sejauh dipikirkan dan dipahami, apa yang asing dapat lebih dimengerti bila yang asing itu mau membuka diri terhadap lokalitas, meskipun kenyataannya tidak selalu demikian. Seringkali pemikiran transnasional berwajah ideologis dalam konteks kebenaran mutlak dan pemaksaan pandangan yang mengerdilkan kearifan lokal dan mengabaikan kemanusiaan itu sendiri.

Secara lebih lanjut, keterbukaan masyarakat Indonesia menunjukkan intensi ke interaksi lebih lanjut dengan aspek lain. Sisi aktif ini muncul sejauh aspek-aspek lain juga bersedia berinteraksi dengan kearifan lokal. Hal ini dapat dilihat dari sejarah agama di Indonesia yang hanya dapat berkembang sejauh berinteraksi baik dengan penduduk lokal. Kedatangan Hindu dan Buddha lewat pengajaran dan persebaran kerajaan di Nusantara, penyebaran Kristen dan Katolik lewat politik etis pada masa kolonial, pemahaman tentang Islam lewat perdagangan dan akulturasi lokal, hingga budaya Konghucu yang berkesesuaian dengan nilai-nilai lokal, adalah contoh persinggungan lokalitas dan transnasionalitas. Tidak ada pemaksaan dalam penyebaran agama-agama tersebut karena yang sesungguhnya terjadi adalah proses saling mengetahui, saling memahami, dan saling membantu satu sama lain. Pluralitas tentu menjadi tumpuan utama bagi proses yang berkelindan tersebut (Maarif dalam Oslo Creation on Freedom of Religion or Belief, 2010:xi). Satu agama dengan yang lain pun tidak saling menegasi namun saling memahami dalam keterbatasannya masingmasing demi kerukunan dan harmoni masyarakat Indonesia.

Menariknya, justru saat ini ideologi seperti kembali ingin ditegakkan di Indonesia. Maraknya instabilitas sosial dianggap sebagai indikasi kurangnya masyarakat yang Pancasilais (Takdir, 2017). Hasilnya, Pancasila kembali ditegakkan sebagai ideologi. Pancasila kembali dibentuk menjadi sebuah hal yang kaku daripada dipahami sebagai pedoman hidup. Memahami Pancasila lalu dianggap perlu untuk dituliskan ke dalam kurikulum pendidikan berbasis pengembangan karakter padahal berbuat etis nyatanya sudah sangat sesuai dengan ide-ide dalam Pancasila. Demikian pula munculnya pihak yang memandang agama sebagai sebuah ideologi. Agama sebagai ideologi dipandang sebagai yang paling benar dan tidak boleh dipersalahkan. Memang benar bahwa kondisi Indonesia cenderung carut-marut, namun menerapkan satu ide tunggal untuk ketidakteraturan tersebut bukanlah hal yang solutif. Kekuasaan justru menjadi tujuan utama ideologi macam itu (Takdir, 2017). Indonesia didorong untuk menjadi sesuai dengan ideologi transnasional tersebut. Saat ini, perluasan ideologi ke arah ekonomi kembali diarahkan ke sisi politis. Aras kepastian dipandang mesti ditegakkan karena logika pluralitas dianggap tak mampu lagi mengatasi masalah.

Dari pemahaman tentang interaksi di atas, justru ideologi transnasional itulah yang harus menyesuaikan diri dengan kearifan lokal. Ideologi transnasional mungkin datang dengan bentuk struktur yang berbeda dari demokrasi Indonesia. Ideologi tersebut menyediakan pilihan lain bagi masyarakat Indonesia terutama dengan sistem yang dianggap benar dan sesuai berkeadilan. Hal itu hanya tercermin pada tingkat 
struktur karena kehidupan sehari-hari menuntut lebih daripada sekedar perkara struktur, yaitu kemampuan untuk berinteraksi secara terbuka dengan pihak lain. Kearifan lokal sudah bersifat terbuka dari awal namun seringkali ideologi transnasional itulah yang memaksa kearifan lokal untuk mengalah, berubah, atau bahkan ditiadakan. Dalam sejarah Indonesia, akulturasi dan asimilasi budaya jauh lebih dimungkinkan daripada penonjolan suatu ideologi tertentu mengalahkan yang lain. Justru pemikiran transnasional yang mau merendah dan berdialog dengan kearifan lokal itulah yang dapat diterima dengan baik. Dalam konteks agama, jelas bahwa sila pertama Pancasila tidak berdiri sendiri namun berkaitan dengan keempat sila lain. Artinya, sejauh manusia memeluk suatu agama, ia melalui suara hatinya yang mengarah kepada Tuhan sekaligus menghidupi kemanusiaan, persatuan, kerakyatan, dan keadilan.

Pada konteks kearifan lokal, agama, kepercayaan, atau keyakinan, dipandang sebagai pedoman hidup yang baik dan terbuka untuk membentuk keselarasan antara Tuhan, sesama manusia, dan keseluruhan alam semesta. Hal tersebut sama dengan apa yang terlihat pada sila pertama Pancasila tentang ketuhanan itu sendiri. Mau tidak mau kondisi tersebut bersinggungan dengan ideologi transnasional pada era globalisasi. Pada satu sisi, ideologi transnasional yang sudah dikenal baik oleh masyarakat Indonesia terus menjaga kerukunan dan kebangsaan untuk keberlanjutan interaksi etis manusia lebih lanjut. Enam agama dan beragam aliran kepercayaan di Indonesia berada dalam konteks ini yaitu multi-dimensional dalam kesetaraan dan keharmonisan. Multi-dimensionalitas ini dibangun dengan memperkuat interaksi sosio-kultural antara yang asing dan yang lokal di Indonesia dalam bingkai pemahaman yang etis akan keterbukaan. Kondisi ini memungkinkan keberagaman kebenaran dalam tiap agama namun dengan tetap memampukan persentuhan interaktif antar elemennya. Agama lebih dipandang sebagai semangat etis bagi orang lain daripada hanya sepenuhnya bergantung pada tafsir tunggal kitab suci (MagnisSuseno, 1987:17).

Meskipun demikian, beberapa tahun terakhir, Indonesia diwarnai oleh kekerasan fisik, verbal, maupun virtual, berlatarbelakang agama yang mengikis rasa toleransi beragama. Ada ideologi transnasional yang meskipun sudah dikenal oleh masyarakat Indonesia namun tidak mau membuka diri sepenuhnya terhadap kearifan lokal. Pemikiran semacam ini melihat perbedaan bukan dalam pemahaman melainkan dengan pembedaan satu dan yang lain. Gesekan justru makin sering terjadi karena ketiadaan kompromi dalam setiap interaksi dengan lokalitas. Apa yang ideologi macam ini inginkan justru dipaksakan untuk diwujukan di Indonesia tanpa memandang kekayaan kearifan lokal. Ideologi ini lebih memilih berteriak-teriak membela kemutlakan agamanya daripada memraktekkan kebaikan agamanya di ruang publik. Ciri khas ideologi ini adalah absolutisme agama dalam politik mengarah ke berbagai sisi sosial-budaya. Pancasila pun ditentang karena dianggap tidak sesuai dengan kemurnian ajaran agama tertentu (Takdir, 2017). Ideologi berkonsep populisme agama ini bersifat uni-dimensional dalam pengertian bahwa satu kebenaran dianggap sudah cukup untuk mengatasi semua hal. Ia bersifat tertutup karena menganggap kebenaran lain itu salah bahkan harus dimusuhi hingga dimusnahkan. Tidak ada dialog etis dalam kondisi ini karena kemungkinan adanya kebenaran lain sudah tertutup sejak awal.

Kemutlakan dan kepastian yang ditonjolkan oleh ideologi transnasional adalah cerminan dari kondisi yang tertutup itu sendiri. Ketertutupan ini selayak tembok yang membatasi satu identitas yang dianggap benar dengan identitas lain. Karena ia 
dianggap benar, maka yang lain tidak perlu dianggap ada bahkan perlu untuk disingkirkan. Ideologi sangat subjektif karena mendasarkan diri pada dogma yang tertutup dan dalam kerangka keilahian terjustifikasi. Sisi subjektif tersebut bukan bertumpu pada kemajemukan pengalaman kehidupan sehari-hari individu melainkan pada sebuah hal yang sudah dipastikan benar dan dianggap pasti sesuai untuk semua hal. Nyatanya, hal ini tidak pernah sesuai dengan kehidupan di Indonesia. Keberagaman Indonesia tercermin dalam semua hal tanpa terkecuali. Apa yang dipahami oleh individu secara partikular bersinggungan secara langsung dengan struktur. Pancasila menjadi dasar dari keberagaman tersebut; bukan dengan mendikte satu kebenaran tetentu melainkan menjadi wadah atas berbagai identitas yang setiap harinya saling memaknai satu sama lain. Demikian pula Pancasila dalam hal ini sebenarnya bukan berinduk pada sila pertama melainkan yang kedua. Kemanusiaan adalah yang utama di Indonesia daripada ketuhanan. Ketuhanan harus berlandaskan kemanusiaan pula sehingga manusia yang berbeda dalam kenyataan dan kebiasaannya dapat dihargai keberagamannya.

Sesungguhnya, interaksi antara ideologi transnasional dan kearifan lokal adalah tentang kemungkinan yang etis. Kebenaran pihak lain hanya mungkin dipahami dalam interaksi yang etis. Interaksi tersebut hanya dapat terjadi jika keduanya saling berusaha mewujudkan toleransi dalam semangat lokalitas dan kebangsaan. Toleransi etis ini bermakna saling memahami sekaligus saling mengetahui keterbatasan masingmasing. Tidak bisa semua hal secara bersama-sama menonjolkan kelebihan mereka apalagi dengan meminggirkan sisi yang lain. Tiap hal saat ini berkelindan dengan yang lain sehingga kepercayaan bukanlah tentang ketunggalan yang tunggal, melainkan ketunggalan yang beragam atau keberagaman yang tunggal seperti dalam Bhinneka Tunggal Ika. Hal yang saat ini terjadi adalah mereka menegakkan kebenaran sendiri dalam konteks egoisme namun dengan menghina kebenaran orang lain. Agama yang seharusnya menjadi rahmat bagi manusia diinterpretasi oleh ideologi ini menjadi doktrin pemaksa (Maarif dalam Oslo Creation on Freedom of Religion or Belief, 2010:xii). Ideologi transnasional tidak perlu dibatasi namun pandangan tersebut perlu memperhatikan kearifan lokal sebagai tumpuan bermasyarakat di Indonesia. Seseorang tidak bisa datang, menutup diri, dan memaksakan kehendaknya, karena setiap tempat memiliki karakteristik sendiri sesuai dengan nilai kemanusiaan dan kebersamaan. Demikian pula masalah agama bukan hanya perkara politik saja melainkan lebih mengarah ke interaksi yang etis dan toleran. Politik perlu untuk dikembalikan sebagai sarana mewujudkan apa yang terbaik untuk publik daripada sekedar perjuangan kepentingan tertentu untuk menguasai keseluruhan Indonesia.

Kearifan lokal tetap akan bertahan di Indonesia sejauh masyarakat menghidupi intersubjektivitas dalam tiap interaksinya. Kearifan lokal adalah tentang budaya, sejarah, dan pengalaman sehari-hari tiap individu yang terkuatkan dalam lokalitas (NU Online, 2007). Hal tersebut mengandaikan adanya persinggungan yang erat dengan individu lain. Kearifan lokal tidak mengajarkan indvidu dan masyarakat untuk menjadi tertutup namun menghidupi kebiasaan individu yang berjalan bersama entitas lain termasuk alam dan manusia. Individu tidak pernah bisa sepenuhnya subjektif, kecuali subjektivitasnya dipertimbangkan dengan subjektivitas individu lain, yang adalah intersubjektivitas itu sendiri. Tiap individu tidak bisa berpegang teguh dengan identitasnya sendiri namun hanya dapat mengaplikasikannya dalam masyarakat dengan keberagaman di dalamnya. Keberagaman tersebut adalah kearifan lokal, yang bukan tercermin dalam kekokohan identitas tunggal, melainkan dalam bagaimana identitas selalu berhadapan dengan identitas yang lain (Takdir, 2017). 
Dengan kata lain, kearifan lokal adalah tentang menghargai entitas lain bahkan yang berbeda dengan dirinya sendiri. Dengan menghargai yang lain, seseorang sebenarnya menghargai dirinya sendiri dan keterbukaan dalam prosesnya. Intersubjektivitas tidak melihat dari bagaimana subjek bertindak kepada objek melainkan bagaimana jika ia adalah objek yang dikenai tindakan. Untuk dapat dihargai, individu perlu menghargai individu lain. Kearifan lokal seperti tercermin dalam Pancasila mengajarkan keselarasan yang melingkupi semua hal dan bukan bersifat ideologis (Saeno, 2017). Pada konteks agama, suatu agama dianggap baik bukan karena ia adalah benar dalam dirinya sendiri melainkan karena ia mampu berbuat baik kepada entitas yang lain. Agama perlu memahami entitas lain dan bukan malah yang lain dipaksa untuk memahaminya. Seringkali agama yang ideologis muncul ke permukaan sebagai sebuah perbedaan yang ingin dihargai namun seringkali pula justru mereka sendiri tak mau menghargai yang lain. Agama tidak bisa ideologis dengan menutup diri dan memaksa yang lain untuk menghargainya. Ia perlu untuk terbuka terhadap tiap interaksi yang mungkin muncul.

\section{Pancasila sebagai Kearifan Lokal yang Adaptif terhadap Ilmu Pengetahuan}

Bangsa Indonesia tidak dapat dilepaskan dari Pancasila sebagai dasar negaranya. Pancasila sendiri merupakan falsafah yang unik, karena hanya ada di Indonesia. Sukarno, Presiden Indonesia pertama menggali Pancasila dari nilai-nilai kebudayaan Indonesia yang tentu saja khas jika dibandingkan dengan bangsa-bangsa lain. Sukarno sendiri membanggakan Pancasila sebagai nilai-nilai yang dapat menciptakan perdamaian dunia, seperti yang diutarakan dalam pidatonya di sidang umum PBB pada 30 September 1960 (Presidenri.go.id, 2016). Namun sebagai sebuah teks, Pancasila mengalami perubahan pemahaman dan penekanan seiring bergantinya rezim yang dinamikanya tersendiri dalam tatanan masyarakat. Dalam kehidupan sehari-hari, Pancasila tidak banyak banyak disebut, kecuali dalam pendidikan formal dan lambang Garuda Pancasila yang menghiasi ruang-ruang kelas dan kantor pemerintahan. Namun belakangan ini, Pancasila kembali menjadi perbincangan hangat di antara masyarakat, dalam konteks menanggapi perihal kebhinnekaan, toleransi, dan bagaimana suatu individu atau organisasi dapat disebut sesuai atau bertentangan dengan Pancasila.

Presiden Joko Widodo, pada 29 Mei 2017 dalam akun instagramnya @jokowi mengunggah video yang menyatakan sikapnya terhadap Pancasila. Video ini kemudian disikapi oleh masyarakat dunia maya dengan mengunggah foto dengan tulisan "Saya Indonesia, Saya Pancasila", yang dengan segera menjadi viral (Kompas.com, 2017). Unggahan video oleh Presiden tersebut bertepatan dengan momentum hari ulang tahun Pancasila pada 1 Juni, dan dinilai berperan sebagai respon terhadap gerakangerakan politik identitas yang dikabarkan berniat menggantikan Pancasila, yang dalam tulisan ini dapat digolongkan sebagai gerakan ideologi transnasional.

Rangkaian perayaan hari ulang tahun Pancasila juga diikuti oleh dibentuknya Unit Kerja Presiden Pembinaan Ideologi Pancasila (UKP PIP) pada 1 Juni 2017. Pembentukan lembaga tersebut didasarkan pada Peraturan Presiden Nomor 54 Tahun 2017, dimaksudkan untuk memperkuat implementasi Pancasila yang terintegrasi dengan program pembangunan, diantaranya termasuk program pengentasan kemiskinan, pemerataan kesejahteraan, dan lain sebagainya (Detik.com, 2017). UKP PIP ini kemudian diperkuat posisi dan perannya menjadi Badan Pengembangan Ideologi Pancasila (BPIP) sehingga dapat terus ada walaupun terjadi pergantian rezim pemerintahan. 
Usaha Presiden Joko Widodo untuk merevitalisasi Pancasila pada dasarnya patut diapresiasi. Namun kebijakan ini bukan berarti tidak bermasalah. Unit Kerja Presiden yang menekankan pada "pembinaan ideologi" sebetulnya serupa dengan apa yang dilakukan rezim Orde Baru dan memiliki artikulasi yang berbeda dengan apa yang dicita-citakan Sukarno sebagai salah satu penggagasnya. Rezim Orde Baru melembagakan Pancasila sebagai asas tunggal yang mutlak harus dianut semua lembaga dari berbagai bidang. Lebih jauh, penetapan Pancasila sebagai asas tunggal ini lebih menjadi alat untuk melanggengkan kekuasaan ketimbang untuk mencapai suatu masyarakat Indonesia yang ideal. Contohnya adalah penghilangan paksa tokoh dan mahasiswa yang dianggap membahayakan stabilitas yang menjadi tujuan Orde Baru. Dengan memberi label anti-pancasila atau tidak pancasilais kepada lawan politik, rezim pemerintah mempunyai legitimasi untuk melakukan apa pun termasuk tindakan-tindakan yang sebetulnya inkonstitusional.

Ketika Pancasila ditafsirkan sebagai sebuah ideologi dan asas tunggal yang mengikat, Pancasila menjadi statis, karena Pancasila sendiri merupakan lima asas yang berisi retorika panjang tanpa petunjuk dan perumusan yang pasti yang dapat memungkinkan perubahan sosial ke arah yang lebih baik. Berkaitan dengan hal ini, Michael Morfit melihat bahwa Pancasila sebagai ideologi semasa Orde Baru lebih berperan sebagai alat pengurung (containment) bagi paham-paham yang tidak disukai rezim, alih-alih sebagai alat mobilisasi masyarakat untuk menggerakkan aksi memenuhi kepentingan nasional (Morfit, 1981:846). Orde Baru menggunakan Pancasila untuk membentuk masyarakat yang patuh dan pasif guna meminimalisasi gangguan terhadap program pembangunan yang dilakukan Pemerintah (Morfit, 1981:848). Dengan demikian, rakyat dijauhkan dari politik, baik sebagai praksis maupun pengetahuannya.

Sementara itu, Pancasila pada masa demokrasi terpimpin Sukarno mempunyai penekanan yang berbeda. Dalam sebuah tulisan untuk merayakan ulang tahun Pancasila 1 Juni 1964, berjudul "Tjamkan Pantja Sila! Pancasila Dasar Falsafah Negara", Sukarno menjabarkan pengertian pokok Pancasila. Pertama, Pancasila sebagai pemerasan kesatuan bangsa Indonesia. Kedua, sebagai manifestasi persatuan bangsa dan wilayah Indonesia. Ketiga sebagai "weltanschauung" Indonesia, yakni pandangan atas dunia, secara nasional maupun internasional (Berdikarionline.com, 2017).

Sukarno dalam penjelasannya mengenai Pancasila dan konteksnya dengan Manipol-USDEK, juga menyatakan bahwa Pancasila digali dari tradisi masyarakat Indonesia dan berjalan seiring dengan jiwa bangsa Indonesia sejak dahulu kala. Dalam pengertian ini, Sukarno berupaya memberikan penekanan pada akar historis Pancasila sebagai bagian dari identitas nasional Indonesia. Dalam pemahaman historis inilah kita dapat melihat kembali bahwa Pancasila pada dasarnya adalah penggalian Sukarno terhadap kearifan-kearifan lokal bangsa Indonesia yang sangat majemuk.

Sukarno mempunyai pemahaman yang lebih terbuka mengenai Pancasila dalam konteks memandang ideologi-ideologi besar saat itu. Profesor Bernhard Dahm, seorang peneliti Jerman yang ahli mengenai Indonesia dan Asia Tenggara sejak 1960an, menceritakan pengalamannya mewawancarai Sukarno mengenai keyakinannya terhadap Pancasila, yang walaupun lekat dengan pandangan NASAKOM, namun pemahamannya masih dapat dijadikan pelajaran bagi kita saat ini;

“... Saya berikan mereka Pancasila, kata Soekarno. Saya yakinkan kaum Marxis, agar mereka menerima prinsip Ketuhanan. Lalu saya yakinkan kubu Islamis, bahwa ajaran Marx adalah analisa jitu yang memberi kita instrumen untuk 
mencapai keadilan sosial. Kalau mereka semua mau saling menerima dan melepaskan doktrin-doktrin yang ditolak pihak lain, maka Indonesia akan Berjaya. Dan mereka semua, kubu agama dan kubu sosialis, mau menerima Pancasila demi kepentingan nasional." (Dahm dalam DW.com, 2017).

Pemahaman Sukarno sebagai penggagas dan penggali menghendaki Pancasila berperan sebagai rumah yang menampung berbagai ideologi, pemahaman, dan pemikiran untuk saling berkontestasi dalam menyumbangkan buah karyanya untuk bangsa Indonesia. Bagi Sukarno, Pancasila berperan lebih sebagai rumah bagi ideologiideologi, dimana dalam pengandaian sebagai rumah ini berbagai ideologi yang ada diharuskan untuk bertoleransi satu sama lain dan memberikan yang terbaik untuk kehidupan bersama. Masing-masing ideologi yang berkontestasi diharuskan untuk mau saling menerima dan melepaskan doktrin yang bertentangan dengan pihak lainnya, dengan kata lain masing-masing harus mampu berkompromi demi kepentingan nasional. Kontestasi ideologi ini juga penting artinya untuk mengembalikan kembali dunia perpolitikan Indonesia menjadi lebih idealistik. Politik nir-ideologi seperti masa sekarang sangat rentan pada money politics dan korupsi, serta jauh dari pemikiran-pemikiran politik yang idealistik.

Sejak awal pendiriannya, Indonesia adalah bangsa yang menampung ideologiideologi transnasional. Kesemuanya itu dipertemukan dengan kearifan lokal, diambil intisarinya, dan direproduksi menjadi Pancasila. Pancasila sebagai produk kultural dan politik dari kehidupan yang majemuk dan kesadaran lokal bangsa Indonesia, seharusnya bisa menjadi payung yang mampu mengayomi berbagai ideologi transnasional. Salah satu bentuknya adalah memahami Pancasila sebagai pengetahuan teologis yang mendampingi ideologi dan agama yang ada. Pancasila hendaknya tidak dipandang sebagai sebuah ideologi namun sebagai acuan pengetahuan bagi ideologiideologi yang diserap masyarakat. Dengan begitu, Pancasila dapat berfungsi untuk menangkal sisi-sisi radikal dari berbagai ideologi.

Walaupun Pancasila digali dari nilai-nilai kebudayaan dan kearifan bangsa Indonesia yang luhur, Pancasila sesungguhnya merupakan kata-kata yang bersifat umum dan penafsirannya bisa diubah sesuai dengan kepentingan rezim yang sedang berkuasa. Pancasila hendaknya tidak dipahami sekadar sebagai asas tunggal, karena hal ini membuat Pancasila kehilangan keluwesannya untuk mengambil apa-apa yang baik dari pemikiran-pemikiran yang ada. Pancasila sebagai asas tunggal menunjukkan transformasinya sebagai ideologi tertutup. Ideologi tertutup yang dimaksud disini adalah ideologi yang totaliter (sekaligus mencakup segala sisi kehidupan termasuk yang privat), mutlak, dan dogmatis, sehingga tidak dapat dikritik maupun diubah lagi. Ideologi yang bersifat tertutup ini menuntut kepatuhan serta ketaatan mutlak bagi masyarakatnya (Guruppkn.com, 2017). Sifat ideologi tertutup ini tidak hanya memberangus ide-ide lain yang dianggap berbeda namun juga menjadi ancaman bagi kebhinnekaan, dimana yang rentan menjadi korban adalah kaum-kaum minoritas.

Ekses dari ketertutupan ideologis ini adalah mandeknya pemikiran-pemikiran untuk memajukan bangsa, karena menjadi terkungkung hanya pada Pancasila. Bagaimanapun Pancasila tidak bisa berdiri sendiri sebagai sebuah asas tunggal, karena masalah-masalah ekonomi, sosial, dan politik akan selalu berkembang dan membutuhkan penyelesaian dengan pendekatan-pendekatan tertentu diluar keterbatasan Pancasila (Beritamoneter.com, 2017). Dalam hal ini, Pancasila bukan obat bagi segala permasalahan negara melainkan pengetahuan tentang keadilan dan kesetaraan seperti terlihat pada sila kelima yakni mengenai keadilan sosial untuk 
seluruh rakyat Indonesia. Sila ini adalah bagian paling kongkrit yang dapat menjamin keberlangsungan kehidupan bangsa yang sejahtera. Keberadaan sila ini sekaligus adalah sebagai tujuan keberadaan Pancasila. Keadilan sosial mencakup kategori yang sangat vital, yakni keadilan secara ekonomis (termasuk kesempatan yang sama dalam meraih sumber-sumber penghidupan, keadilan dalam mengelola tanah, reforma agraria, upah layak, dsb.), keadilan politis (mencakup keadilan dalam kesempatan berpolitik bagi kaum minoritas, kebebasan memeluk ideologi dan ekspresi politik tertentu, dsb.), dan keadilan kultural (keadilan pada ekspresi dan praktik budaya daerah yang belakangan semakin menjadi minoritas). Tanpa wujud-wujud keadilan sosial ini, Pancasila hanya sekadar berfungsi sebagai alat gebuk bagi penguasa.

Masyarakat luas hendaknya diberi kesempatan untuk giat berwacana dalam menginterpretasi kembali Pancasila sehingga pengetahuan tetap bisa terus bereproduksi, dan dengannya menciptakan ideal-ideal baru yang dapat memberikan progress bagi keadilan sosial di Indonesia. Ideologi dan pemikiran baik yang datang dari dalam negeri maupun yang disebarkan secara transnasional, hendaknya dapat turut memberikan sumbangsih pemikirannya, dengan selalu bernaung pada Pancasila sebagai pandangan hidup bangsa. Pancasila memang bukan sebuah ideologi yang mampu mendefinisikan semua hal namun Pancasila menjadi intisari dari setiap pemkiran di Indonesia. Posisi Pancasila tidak berada diatas semua hal namun hal tersebut berada diantara dan disetiap perjalanan pemikiran di Indonesia. Pancasila tidak menunjuk kepastian arti melainkan kemungkinan makna. Dalam hal ini Pancasila tidak membatasi dan mendikte namun justru bisa menjadi basis maupun sarana perkembangan pemikiran kebangsaan lain yang jauh lebih baik.

Seperti diungkapkan oleh Sukarno, Pancasila merupakan weltanschauung bagi bangsa Indonesia, yang diadopsi oleh negara untuk membentuk suatu pandangan yang menyatukan segenap bangsa. Oleh karena itu, weltanschauung berfungsi sebagai batasan-batasan kenegaraan yang disetujui oleh warga negara Indonesia sebagai sebuah pandangan dasar negara. Disinilah mengapa masyarakat Indonesia tidak hanya harus mendapatkan pengetahuan mengenai Pancasila, namun juga menggali Pancasila dalam kehidupan sehari-harinya. Pancasila, sebagai sebuah ideal terbatas pada ruang negara menjadikan dua sifat yang melekat pada dirinya; sebagai ide ia mempunyai potensi yang membebaskan dan mencerahkan, namun keterbatasannya membuatnya bisa diperlakukan sebagai alat politik yang menindas. Tanpa peran masyarakat dalam reproduksi pengetahuan Pancasila, dasar negara ini berpotensi menjadi alat legitimasi bagi suatu rezim untuk melakukan penindasan, seperti yang pernah dialami pada masa Orde Baru. Reproduksi pengetahuan ini diperlukan bukan untuk memunculkan interpretasi maupun versi-versi lain dari Pancasila, namun membuat kondisi di mana masyarakat diberikan peran untuk mengembalikan Pancasila sebagai bagian dari kearifan lokal. Sebagaimana Sukarno menjelaskan inti dari Pancasila menjadi satu sila yakni gotong-royong, semangat untuk mengembalikan Pancasila pada kearifan lokal harus didasari semangat gotong-royong demi memperbaiki kualitas hidup bersama.

Alangkah baiknya apabila BPIP yang dibentuk oleh Presiden Joko Widodo lebih memperhatikan dan menggali kembali aspek kearifan lokal dari Pancasila. Dengan demikian, kearifan lokal kembali mendapatkan tempatnya sebagai bagian dari identitas nasional dan Pancasila dihayati kembali sebagai intisari kearifan lokal, yang dihasilkan dari pengalaman-pengalaman bermasyarakat secara tradisional. Masyarakat tidak perlu dipaksa untuk mengikuti Pancasila, namun dapat menemukannya sendiri dalam kehidupannya sehari-hari. 


\section{KESIMPULAN}

Pancasila pada dasarnya memberikan pemahaman lebih lanjut tentang interaksi kearifan lokal dan ideologi transnasional. Kearifan lokal adalah cerminan dari apa yang telah dipahami dalam pengalaman interaksi dengan lingkungannya sehari-hari, sedangkan ideologi secara umum maupun yang tersebar secara transnasional adalah bagian dari apa yang berada di luarnya. Keduanya memang berbeda satu sama lain namun dapat diterima dan diinternalisasi dengan baik oleh masyarakat Indonesia melalui pemahaman akan Pancasila. Memahami kembali Pancasila berarti menjelaskan kembali bagaimana lokalitas tidak selalu bertentangan dengan transnasionalitas karena keterbukaan kearifan lokal selalu memungkinkan ideologi transnasional untuk berkembang di negeri ini. Keterbukaan adalah karakteristik kearifan lokal yang kemudian disarikan dalam Pancasila. Ideologi maupun pemikiran yang berasal dari luar Indonesia hendaknya bersikap terbuka dan bersedia menghilangkan unsur-unsur doktrinal yang totaliter demi mencapai tujuan nasional. Dengan keterbukaan ideologi-ideologi transnasional ini, dan kemauannya mengakomodasi dan melakukan pendekatan menurut kearifan lokal, maka konsep dan pemikiran asing tersebut dapat diinternalisasi dan diadopsi masyarakat Indonesia dengan langgam kearifan lokalnya masing-masing. Dalam hal interseksi kearifan lokal dan ideologi trasnasional ini, Pancasila sebagai pandangan hidup bangsa bisa juga diposisikan sebagai mediator dua subjek pemikiran yang ada, yaitu antara kearifan lokal dan ideologi transnasional. Dengan kata lain, kearifan lokal dan Pancasila selalu terbuka bagi pemahaman lain sejauh semangat ingin saling memahami dan kegotong-royongan untuk membangun bangsa selalu menjadi dasar bagi setiap interaksi yang ada.

\section{DAFTAR RUJUKAN}

\section{Buku}

Barker, Chris. (2014). Kamus Kajian Budaya (terj.). Yogyakarta: Kanisius.

Ernawi, Imam Santoso. (2009). Kearifan Lokal dalam Perspektif Tata Ruang, dalam Wikantiyoso, Respati dan Tutuko, Pindo (Ed.), Kearifan Lokal: Dalam Perencanaan dan Perancangan Kota. Malang: Malang Group Konservasi Arsitektur dan Kota.

Keraf, Sony. (2006). Etika Lingkungan. Jakarta: Kompas.

Magnis-Suseno, Franz. (1987). Etika Dasar: Masalah-Masalah Pokok Filsafat Moral. Yogyakarta: Kanisius.

Oslo Creation on Freedom of Religion or Belief. (2010). Kebebasan Beragama atau Berkeyakinan: Seberapa Jauh? Sebuah Referensi tentang Prinsip-Prinsip dan Praktek (terj.). Yogyakarta: Kanisius.

Simuh. (1996). Sufisme Jawa. Yogyakarta: Bentang Budaya.

Soebadio, Haryati. (1986). Kepribadian Budaya Bangsa, Ayat Rohaedi, Kepribadian Budaya Bangsa (Local Genius). Jakarta: Pustaka Jaya.

Sunoto. (1989). Filsafat Sosial dan Politik Pancasila. Yogyakarta: Andi Offset.

Sunyoto, Agus. (2016). Atlas Wali Songo. Bandung: Mizan.

Tjahjadi, S.P. Lili (ed.). (2011). Agama dan Demokratisasi: Kasus Indonesia. Yogyakarta: Kanisius.

Viotti, Paul R. dan Mark V. Kauppi. (1999). International Relations Theory. London: Allyn and Bacon.

\section{Jurnal}

Alfian, Magdalia. (2013). Potensi Kearifan Lokal dalam Pembentukan Jati Diri dan Karakter Bangsa, Prosiding $5^{\text {th }}$ International Conference on Indonesia Studies: Ethnicity and Globalization, Yogyakarta. 
Brata, Ida Bagus. (2016). Kearifan Budaya Lokal Perekat Identitas Bangsa, Jurnal Bakti Saraswati, Vol. 5, No. 01, Maret.

Dahliani. et. al. (2015). Local Wisdom in Built Environment in Globalization Era, International Journal of Education and Research, Vol. 3, No. 6, Juni.

Morfit, Michael. (1981). Pancasila: The Indonesian State Ideology According to the New Order Government, Asian Survey, Vol. 21, No. 8.

Mungmachon, R. (2012). Knowledge and Local Wisdom: Community Treasure. International Journal of Humanities and Social Science, Vol. 2, No. 13, Juli.

Widiastuti. (2013). Analisis SWOT Keberagaman Budaya Indonesia, Jurnal Ilmiah WIDYA, Vol. 1, No. 1, Mei-Juni.

\section{Artikel Daring}

Berdikarionline.com. 2017. Asal-Usul Pancasila. Diakses dari www.berdikarionline.com/asal-usul-pancasila, pada tanggal 15 Juni 2018.

Berdikarionline.com. 2012. Nasionalisme Ala Soekarno, Diakses dari http://www.berdikarionline.com/nasionalisme-ala-soekarno/ pada tanggal 1 Agustus 2019

Beritamoneter.com. 2017. RPI: Pancasila Bukan Ideologi Tertutup. Diakses dari www.beritamoneter.com/rpi-pancasila-bukan-ideologi-tertutup, pada tanggal 17 Juni 2018.

Detik.com. 2017. Jokowi Umumkan UKP Pembinaan Ideologi Pancasila Besok. Diakses dari news.detik.com/berita/d-3516650/jokowi-umumkan-ukp-pembinaan-ideologipancasila-besok, pada tanggal 15 Juni 2018.

DW.com. 2017. Soekarno Yakin Pancasila dan NASAKOM Adalah Masa Depan Indonesia. www.dw.com/id/soekarno-yakin-pancasila-dan-nasakom-adalah-masa-depanindonesia/a-19345349, pada tanggal 17 Juni 2018.

Guruppkn.com. 2017. Pancasila sebagai Ideologi Tertutup Mengandung Arti. Diakses dari guruppkn.com/pancasila-sebagai-ideologi-tertutup, pada tanggal 17 Juni 2018.

Keyes, Ralph. 2004. The Post-Truth Era: Dishonesty and Deception in Contemporary Life. Diakses dari www.ralphkeyes.com/the-post-truth-era/, pada tanggal 15 Juni 2018.

Kompas.com. 2017. Jokowi: Saya Indonesia, Saya Pancasila, kalau Kamu? Diakses dari nasional.kompas.com/read/2017/05/30/06171451/jokowi.saya.indonesia.saya.p ancasila.kalau.kamu, pada tanggal 16 Juni 2018.

Majid, Abdul Zamakhsyari. 2016. Pergaulan dalam Pandangan Islam. Diakses dari www.nu.or.id/post/read/73959/pergaulan-dalam-pandangan-islam, pada tanggal 15 Juni 2018.

Marty, Martin E. 2015. International Encyclopedia of the Social \& Behavioral Sciences (Second Edition). Diakses dari https://www.sciencedirect.com/topics/socialsciences/fundamentalism, pada tanggal 1 Oktober 2019.

Marzuki. Nd. Tradisi dan Budaya Masyarakat Jawa Dalam Perspektif Islam. Diakses dari eprints.uny.ac.id/2609/1/5._Tradisi_dan_Budaya_Masyarakat_Jawa_dalam_Perspe ktif_Islam.pdf, pada tanggal 15 Juni 2018.

Metcalf, Stephen, 2017, Neoliberalism: the idea that swallowed the world, diakses dari https://www.theguardian.com/news/2017/aug/18/neoliberalism-the-idea-thatchanged-the-world, pada 14 Oktober 2019

Muzadi, A., Muchith, KH. 2006, Pola Hidup Birul Walidain. Diakses dari www.nu.or.id/post/read/7952/pola-hidup-birul-walidain, pada tanggal 15 Juni 2018. 
NU Online. 2007. Ideologi Transnasional harus Disesuaikan dengan Basis Kebangsaan. Diakses dari www.nu.or.id/post/read/9728/ideologi-transnasional-harusdisesuaikan-dengan-basis-kebangsaan, pada tanggal 10 Maret 2018.

Presidenri.go.id. 2016. Bung Karno, 1 Juni dan Lunasnya Utang Sejarah. Diakses dari presidenri.go.id/berita-aktual/bung-karno-1-juni-dan-lunasnya-utangsejarah.html, pada tanggal 16 Juni 2018.

Saeno (ed.). 2017. Franz Magnis: Ideologi Transnasional Kebanyakan Bertujuan Rusak NKRI. Diakses dari kabar24.bisnis.com/read/20170510/16/652562/franz-magnisideologi-transnasional-kebanyakan-bertujuan-rusak-nkri, ada tanggal 10 Maret 2018.

Santosa, Lia Wanadriani. 2016. Indonesia Terancam Dua Ideologi Transnasional. Diakses dari www.antaranews.com/berita/545292/indonesia-terancam-dua-ideologitransnasional, pada tanggal 10 Maret 2018.

Takdir, Mohammad. 2017. Ideologi Radikal dan Syariat Demokratik. Diakses dari geotimes.co.id/opini/ideologi-radikal-dan-syariat-demokratik/, pada tanggal 10 Maret 2018.

Zainuddin. 2015. Agama dan Kekerasan (Membongkar Wacana Fundamentalisme Agama). Diakses dari https://www.uin-malang.ac.id/r/150701/agama-dan-kekerasanmembongkar-wacana-fundament, pada tanggal 1 Oktober 2019. 